\title{
Bifidobacterium kashiwanohense sp. nov., isolated from healthy infant faeces
}

Correspondence

Hidetoshi Morita morita@azabu-u.ac.jp
Hidetoshi Morita, ${ }^{1}$ Akiyo Nakano, ${ }^{1}$ Hiromi Onoda, ${ }^{1}$ Hidehiro Toh, ${ }^{2}$ Kenshiro Oshima, ${ }^{3}$ Hideto Takami, ${ }^{4}$ Masaru Murakami, ${ }^{1}$ Shinji Fukuda,,${ }^{5,6}$ Tatsuya Takizawa, ${ }^{1}$ Tomomi Kuwahara, ${ }^{7}$ Hiroshi Ohno, ${ }^{5,}{ }^{6}$ Soichi Tanabe ${ }^{8}$ and Masahira Hattori ${ }^{3}$

\footnotetext{
${ }^{1}$ School of Veterinary Medicine, Azabu University, 1-17-71 Fuchinobe, Sagamihara, Kanagawa 229-8501, Japan

${ }^{2}$ Advanced Science Institute, RIKEN, 1-7-22 Suehiro, Tsurumi, Yokohama, Kanagawa 230-0045, Japan

${ }^{3}$ Graduate School of Frontier Sciences, The University of Tokyo, 5-1-5 Kashiwanoha, Kashiwa, Chiba 277-8562, Japan

${ }^{4}$ Microbial Genome Research Group, Japan Agency of Marine-Earth Science and Technology, 2-15 Natsushima, Yokosuka, Kanagawa 237-0061, Japan

${ }^{5}$ Laboratory for Epithelial Immunobiology, RIKEN Research Center for Allergy and Immunology, 1-7-22 Suehiro, Tsurumi, Yokohama, Kanagawa 230-0045, Japan

${ }^{6}$ Graduate School of Nanobioscience, Yokohama City University, 1-7-29 Suehiro, Tsurumi, Yokohama, Kanagawa 230-0045, Japan

${ }^{7}$ Department of Molecular Bacteriology, Institute of Health Biosciences, University of Tokushima, Graduate School, 3-18-15 Kuramoto-cho, Tokushima 770-8503, Japan

${ }^{8}$ Graduate School of Biosphere Science, Hiroshima University, 1-4-4 Kagamiyama, Higashi-Hiroshima, Hiroshima 739-8528, Japan
}

Strains $\mathrm{HM} 2-1$ and $\mathrm{HM} 2-2^{\top}$ were isolated from the faeces of a healthy infant and were characterized by determining their phenotypic and biochemical features and phylogenetic positions based on partial 16S rRNA gene sequence analysis. They were Gram-positive, obligately anaerobic, non-spore-forming, non-gas-producing, and catalase-negative non-motile rods. They did not grow at 15 or $45{ }^{\circ} \mathrm{C}$ in anaerobic bacterial culture medium, and their DNA $\mathrm{G}+\mathrm{C}$ content was in the range 56-59 mol\%. In enzyme activity tests, strains HM2-1 and HM2-2 ${ }^{\top}$ were positive for $\alpha / \beta$-galactosidases and $\alpha / \beta$-glucosidases but negative for $\beta$-glucuronidase and cystine arylamidase. An analysis of the cell-wall composition of strains $\mathrm{HM} 2-1$ and $\mathrm{HM} 2-2^{\top}$ revealed the presence of glutamic acid, alanine and lysine. The presence of fructose-6-phosphate phosphoketolase shows that isolates $\mathrm{HM} 2-1$ and $\mathrm{HM} 2-2^{\top}$ are members of the genus Bifidobacterium. These two isolates belong to the same species of the genus Bifidobacterium. Strain HM2-2 ${ }^{\top}$ was found to be related to Bifidobacterium catenulatum JCM $1194^{\top}(97.4 \% 16 \mathrm{~S}$ rRNA gene sequence identity: $1480 / 1520 \mathrm{bp}$ ), Bifidobacterium pseudocatenulatum JCM $1200^{\top}$ (97.2\%: 1472/1514 bp), Bifidobacterium dentium ATCC $27534^{\top}$ (96.7\%: 1459/1509 bp) and Bifidobacterium angulatum ATCC $27535^{\top}$ (96.5\%: 1462/1515 bp). The predominant cellular fatty acids of strains $\mathrm{HM} 2-1$ and $\mathrm{HM} 2-2^{\top}$ were $16: 0$ and $18: 1 \omega 9 \mathrm{c}$, with proportions greater than $18 \%$ of the total. Phylogenetic analyses involving phenotypic characterization, DNA-DNA hybridization and partial 16S rRNA gene sequencing proves that the strains represent a novel species of the genus Bifidobacterium, for which the name Bifidobacterium kashiwanohense sp. nov. is proposed. The type strain is $\mathrm{HM} 2-2^{\top}\left(=\mathrm{JCM} 15439^{\top}=\mathrm{DSM} 21854^{\top}\right)$.

The GenBank/EMBL/DDBJ accession numbers for the 16S rRNA and partial hsp60 gene sequences of strain HM2-1 are AB491757 and AB578933, respectively. Those for strain HM2-2 ${ }^{\top}$ are AB425276.2 and AB491759.2, respectively.

Four supplementary figures are available with the online version of this paper. 
The genus Bifidobacterium represents one of the bacterial groups within the class Actinobacteria and is prevalent within the gastrointestinal tracts of humans and animals (Mikkelsen et al., 2003). At the time of writing, the genus Bifidobacterium is represented by over 30 species and subspecies, and the type strains of Bifidobacterium adolescentis, $B$. angulatum, B. bifidum, B. breve, B. catenulatum, $B$. dentium, $B$. longum subsp. infantis, $B$. longum subsp. longum, B. pseudocatenulatum and B. scardovii were isolated from human specimens (Scardovi, 1986; Hoyles et al., 2002; Sakata et al., 2002). The bifidobacteria have not been found to cause human diseases; instead, they are considered to be probiotic micro-organisms (Fuller, 1991; Ventura et al., 2009; Whorwell et al., 2006; Brenner et al., 2009).

During our studies, two isolates, HM2-1 and HM2-2 ${ }^{\mathrm{T}}$, from faeces of a healthy infant were not identified to the species level. Our results show that these isolates represent a novel Bifidobacterium species, for which the name Bifidobacterium kashiwanohense sp. nov. is proposed.

We isolated 51 strains of putative bifidobacteria inhabiting the faeces of a healthy infant (male; 1.5 years old) in 2008. Blood liver (BL) agar plates (Eiken Chemical) and anaerobic bacterial culture medium (ABCM broth; Eiken Chemical) were used for cell cultures. All 51 isolates were anaerobically cultured at $37{ }^{\circ} \mathrm{C}$ in $\mathrm{ABCM}$ broth and on BL agar plates for 24 and $72 \mathrm{~h}$, respectively. Of the 51 isolates, Bifidobacterium longum subsp. longum (20 strains), B. longum subsp. infantis (2 strains), B. bifidum (6 strains) and B. breve (3 strains) were identified, whereas the other isolates (20 strains) were not identified to the species level. Of the 20 other isolates, the unidentified strains HM2-1 and HM2-2 ${ }^{\mathrm{T}}$ formed a subcluster in the genus Bifidobacterium in the taxonomic study. Strains HM2-1 and HM2-2 ${ }^{\mathrm{T}}$ were found to be Grampositive, obligately anaerobic, non-spore-forming, non-gasproducing and catalase-negative non-motile rods. Table 1 shows the major characteristics of isolates HM2-1 and HM2-2 ${ }^{\mathrm{T}}$, and the related strains B. catenulatum JCM $1194^{\mathrm{T}}$, B. pseudocatenulatum JCM $1200^{\mathrm{T}}$, B. dentium JCM $1195^{\mathrm{T}}$ and $B$. angulatum JCM $7096^{\mathrm{T}}$. The results were recorded after $48 \mathrm{~h}$ at $37^{\circ} \mathrm{C}$. The isomer of lactic acid produced from $\mathrm{D}$-glucose was determined by using an F-kit $[\mathrm{D}(-)$-lactic $\operatorname{acid} / \mathrm{L}(+)$-lactic acid; Roche]. Other biochemical tests on motility, growth at a fixed temperature and gas production from D-glucose were performed using the methods described by Mitsuoka (1969). The optimal temperature for growth of strains HM2-1, HM2-2 ${ }^{\mathrm{T}}$, JCM $7096^{\mathrm{T}}$ and JCM $1194^{\mathrm{T}}$ was $37^{\circ} \mathrm{C}$; no growth was observed at 15 or $45^{\circ} \mathrm{C}$ in ABCM broth. Although all strains grew at $\mathrm{pH} 7.2$ and $\mathrm{pH} 8.0$, no growth was observed at $\mathrm{pH} 4.5$. B. pseudocatenulatum JCM $1200^{\mathrm{T}}$ grew weakly at $45^{\circ} \mathrm{C}$ and $\mathrm{pH}$ 4.5. B. dentium JCM $1195^{\mathrm{T}}$ grew at $\mathrm{pH}$ 4.5. Acid production from carbohydrates in ABCM broth is shown in Table 1. For the determination of phenotypic characteristics, API ZYM tests (bioMérieux) were performed in duplicate using the methods recommended by the manufacturer. Cells were collected from each ABCM culture by centrifugation at 12000 r.p.m. for $5 \mathrm{~min}$, inoculated onto the test strips and
Table 1. Physiological characteristics of isolates HM2-1 and $\mathrm{HM} 2-2^{\top}$ and the type strains of closely related species of the genus Bifidobacterium

Strains: 1, HM2-1; 2, HM2-2 $2^{\mathrm{T}} ; 3$, B. catenulatum JCM $1194^{\mathrm{T}} ; 4$, B. pseudocatenulatum JCM $1200^{\mathrm{T}} ; 5$, B. dentium JCM $1195^{\mathrm{T}} ; 6, B$. angulatum JCM $7096^{\mathrm{T}}$. +, Positive; -, negative; $\mathrm{W}$, weakly positive. All strains were positive for the following characteristics: fermentation of glucose, fructose, mannose, maltose and sucrose; growth in $\mathrm{ABCM}$ broth at $37{ }^{\circ} \mathrm{C}$, at intial $\mathrm{pH} 7.2$ and 8.0, and under anaerobic conditions; no growth in $\mathrm{ABCM}$ broth at $15{ }^{\circ} \mathrm{C}$ under anaerobic conditions. All strains produced L-lactic acid and did not produce gas from D-glucose. All strains produced acid from D-xylose, D-ribose, Larabinose, D-glucose, D-galactose, sucrose, maltose, lactose, melibiose, raffinose and salicin. None of the strains produced acid from glycerol or rhamnose. All strains possessed leucine arylamidase, $\alpha$-galactosidase, $\beta$-galactosidase, $\alpha$-glucosidase and $\beta$-glucosidase; none possessed alkaline phosphatase, esterase (C4), lipase (C14), valine arylamidase, trypsin, $\alpha$-chymotrypsin, naphthol-AS-BI-phosphohydrolase, $N$-acetyl- $\beta$-glucosaminidase, $\alpha$-mannosidase or $\alpha$-fucosidase. DNA $\mathrm{G}+\mathrm{C}$ contents were determined by HPLC.

\begin{tabular}{|c|c|c|c|c|c|c|}
\hline Characteristic & 1 & 2 & 3 & 4 & 5 & 6 \\
\hline \multicolumn{7}{|l|}{ Growth at: } \\
\hline $45^{\circ} \mathrm{C}$ & - & - & - & $\mathrm{W}$ & - & - \\
\hline Initial $\mathrm{pH} 4.5$ & - & - & - & $\mathrm{W}$ & + & - \\
\hline \multicolumn{7}{|l|}{ Acid from: } \\
\hline D-Mannose & + & $\mathrm{W}$ & - & + & + & - \\
\hline Cellobiose & + & + & + & + & + & - \\
\hline Trehalose & - & - & - & + & + & - \\
\hline Melezitose & - & - & - & - & $\mathrm{W}$ & - \\
\hline Dextrin & $\mathrm{W}$ & $\mathrm{W}$ & $\mathrm{W}$ & + & + & + \\
\hline Starch & - & - & - & + & + & + \\
\hline Inulin & - & $\mathrm{W}$ & - & - & - & + \\
\hline D-Mannitol & - & - & - & - & + & - \\
\hline D-Sorbitol & + & + & + & + & - & - \\
\hline D-Fructose & + & + & + & + & $\mathrm{w}$ & + \\
\hline \multicolumn{7}{|l|}{ API ZYM } \\
\hline Esterase lipase (C8) & + & + & + & - & - & - \\
\hline Cystine arylamidase & - & - & + & - & - & - \\
\hline Acid phosphatase & + & + & + & + & + & - \\
\hline$\beta$-Glucuronidase & - & - & - & - & + & - \\
\hline $\begin{array}{l}\text { DNA G }+ \text { C content } \\
\quad(\mathrm{mol} \%)\end{array}$ & 58.6 & 56.3 & 54.7 & 57.5 & 61.2 & 59.0 \\
\hline
\end{tabular}

incubated for $4 \mathrm{~h}$ at $37{ }^{\circ} \mathrm{C}$. Nineteen enzymic activities were estimated by the API ZYM tests, and strains HM2-1 and HM2-2 ${ }^{\mathrm{T}}$ showed 7 enzymic activities (Table 1$)$. Enzyme activity tests were positive for $\alpha / \beta$-galactosidases and $\alpha / \beta$ glucosidases but negative for $\beta$-glucuronidase and cystine arylamidase. Isolates HM2-1 and HM2-2 ${ }^{\mathrm{T}}$ had fructose-6phosphate phosphoketolase activity like the reference strains (Biavati \& Mattarelli, 1991; Gavini et al., 1991). An analysis of the cell-wall composition revealed the presence of glutamic acid, alanine and lysine by ultraperformance liquid chromatography according to the methods described by Komagata \& Suzuki (1987). The ACQUITY UPLC System (Waters) was used in this study. Whole-cell fatty acid methyl 
esters were obtained by saponification, methylation and extraction followed by analysis using a standardized Microbial Identification System (Microbial ID) (Tan et al., 2010). The Sherlock standard library MOORE5 5.00 made it possible to standardize the bacterial fatty acid analysis (http://www.midi-inc.com) in Table 2.

The DNA G + C contents of strains HM2-1 and HM2-2 ${ }^{\mathrm{T}}$ were determined in three separate trials by high-performance liquid chromatography (Okamoto et al., 2008). The DNA G + C contents of strains HM2-1 and HM2-2 ${ }^{\mathrm{T}}$ were 58.6 and $56.3 \mathrm{~mol} \%$, respectively. These differ from the values obtained for B. catenulatum JCM $1194^{\mathrm{T}}$ and $B$. dentium JCM $1195^{\mathrm{T}}$, whose DNA G $+\mathrm{C}$ contents were 54.7 and $61.2 \mathrm{~mol} \%$, respectively (Scardovi \& Crociani, 1974). However, the DNA G $+\mathrm{C}$ content of strains HM2-1 and HM2-2 ${ }^{\mathrm{T}}$ were similar to those of $B$. pseudocatenulatum JCM $1200^{\mathrm{T}}(57.5 \mathrm{~mol} \%)$ and B. angulatum JCM $7096^{\mathrm{T}}$ (59.0 mol\%) (Scardovi \& Crociani, 1974; Scardovi et al., 1979).

The 16S rRNA genes of strains HM2-1 and HM2-2 ${ }^{\mathrm{T}}$ were amplified by PCR using the universal primers $27 \mathrm{~F}$ and 1492R (Weisburg et al., 1991). The closest known relatives of the isolate were determined by performing database searches, and the sequences of closely related species were retrieved from public databases. Multiple alignments of the sequences were carried out using CLUSTAL W (Thompson et al., 1994). We used the neighbour-joining method to

Table 2. Cellular fatty acid contents (\%) of isolates HM2-1 and $\mathrm{HM} 2-2^{\top}$ and the type strains of closely related species of the genus Bifidobacterium

Strains: 1, HM2-1; 2, HM2-2 $2^{\mathrm{T}}$, 3, B. catenulatum; 4, B. pseudocatenulatum; 5, B. dentium; 6, B. angulatum. Data for reference strains were obtained from the standard Library MOORE5 5.00 of the Sherlock Microbial Identification System.

\begin{tabular}{|lcccccc|}
\hline Fatty acid & $\mathbf{1}$ & $\mathbf{2}$ & $\mathbf{3}$ & $\mathbf{4}$ & $\mathbf{5}$ & $\mathbf{6}$ \\
\hline $10: 0$ & 1.6 & 2.1 & 0.7 & 1.2 & 0.7 & 1.5 \\
$12: 0$ & 3.8 & 8.1 & 1.3 & 2.9 & 1.2 & 2.7 \\
$11: 0 \mathrm{DMA}$ & 0.6 & 0.8 & 0.7 & 0.5 & 0 & 0 \\
$14: 0$ & 6.8 & 15.9 & 5.3 & 10.5 & 5.1 & 8.4 \\
$14: 0 \mathrm{DMA}$ & 2.7 & 3.3 & 3.5 & 2.7 & 2.9 & 2.1 \\
$16: 1 \omega 9 c$ & 3.4 & 6.3 & 2.2 & 2.2 & 1.8 & 2.6 \\
$16: 1 \omega 7 c$ & 0 & 0 & 1.8 & 3.9 & 1.1 & 2.6 \\
$16: 0$ & 30.3 & 26.8 & 25.7 & 13.7 & 25.8 & 18.1 \\
$16: 0$ DMA & 0.9 & 0.7 & 0.5 & 0 & 0 & 0 \\
$16: 1 \omega 7 c$ DMA & 0 & 0 & 1.1 & 0.5 & 0 & 0.6 \\
$17: 0$ anteiso & 0 & 0 & 0 & 0.7 & 0 & 0 \\
$18: 2 \omega 6,9 c$ & 0.8 & 1.1 & 0 & 0 & 0 & 0 \\
$18: 1 \omega 9 c$ & 18.1 & 19.4 & 18.3 & 33.6 & 22.8 & 33.5 \\
$18: 0$ & 6.1 & 2.5 & 3.3 & 2.3 & 6.9 & 3.7 \\
$18: 1 \omega 7 c$ DMA & 0 & 0 & 0.6 & 0 & 0 & 0 \\
$18: 012-\mathrm{OH}$ & 0 & 0 & 1.5 & 0 & 0.6 & 0 \\
$18: 1 \omega 9 c$ DMA & 19.1 & 9.1 & 23.3 & 12.2 & 23.2 & 14.3 \\
$18: 0$ DMA & 0 & 0 & 0 & 0 & 0.6 & 0 \\
\hline
\end{tabular}

reconstruct a phylogenetic tree (Saitou \& Nei, 1987) and estimated the robustness of the individual branches by performing bootstrapping analysis with 1000 replicates (Felsenstein, 1985). Phylogenetic trees were also reconstructed using the maximum-likelihood (Cavalli-Sforza \& Edwards, 1967) and maximum-parsimony (Kluge \& Farris, 1969) methods with PHYLIP version 3.66. The partial $16 \mathrm{~S}$ rRNA gene sequence of strain HM2-2 $2^{\mathrm{T}}$ was consistent with that of strain HM2-1. DNA-DNA hybridization was carried out using the microdilution-well technique, with photobiotin for DNA labelling (Ezaki et al., 1989). Immobilized DNA in microdilution wells was incubated with a photobiotin-labelled DNA probe prepared from each strain at $48{ }^{\circ} \mathrm{C}$ for $3 \mathrm{~h}$ in hybridization buffer containing $50 \%$ formamide, after $30 \mathrm{~min}$ of incubation at $37^{\circ} \mathrm{C}$ in prehybridization buffer. The fluorescence intensity was measured with a MicroPlate reader (PerkinElmer) at a wavelength of $360 \mathrm{~nm}$ for excitation and $450 \mathrm{~nm}$ for emission. Values (\%) of DNA-DNA hybridization were the mean of the two trials in this study. Strains HM2-1 and HM2-2 ${ }^{\mathrm{T}}$ shared high levels of DNA-DNA relatedness $(92.1 \%)$. We analysed the DNA profile by random amplified polymorphic DNA (RAPD) PCR performed using the random primers 103 (5'-GTGACGCCGC-3'), $127\left(5^{\prime}\right.$ ATCTGGCAGC-3') and 173 (5'-CAGGCGGCGT-3') (University of British Columbia) to compare strains HM21 and HM2-2 ${ }^{\mathrm{T}}$. Their RAPD profiles (Supplementary Fig. S1 available in IJSEM Online) showed that they were different strains of the same species, supported by phenotypic and biochemical features and their phylogenetic position based on partial 16S rRNA gene sequence and DNA-DNA hybridization analyses.

Two organisms are considered to represent the same species if their purified DNA exhibits greater than $70 \%$ hybridization (Wayne et al., 1987). DNA-DNA hybridization analysis was carried out comparing isolates HM2-1 and HM2-2 $2^{\mathrm{T}}$ and other related strains listed in Table 1 according to the method previously by Ezaki et al. (1989). DNA-DNA relatedness values between strain HM2-2 ${ }^{\mathrm{T}}$ and B. catenulatum JCM $1194^{\mathrm{T}}$ were $8.1 \% \pm 1.6 \%$ and $14.6 \% \pm 2.4 \%$ using the probes for $\mathrm{HM} 2-2^{\mathrm{T}}$ and $B$. catenulatum JCM $1194^{\mathrm{T}}$, respectively. DNA-DNA relatedness values using the reference strains as DNA probes for strain HM2-2 $2^{\mathrm{T}}$ were as follows: HM2-2 ${ }^{\mathrm{T}}$ and B. pseudocatenulatum $\mathrm{JCM} 1200^{\mathrm{T}}(6.5 \%), \mathrm{HM} 2-2^{\mathrm{T}}$ and B. dentium $\mathrm{JCM} 1195^{\mathrm{T}}(5.7 \%)$, and HM2-2 ${ }^{\mathrm{T}}$ and B. angulatum JCM $7096^{\mathrm{T}}(6.8 \%)$.

We reconstructed a phylogenetic tree based on a total of 44 partial 16S rRNA gene sequences, including those of members of the genus Bifidobacterium and related genera. The tree was rooted using Actinomyces bovis (Fig. 1). Strains HM2-1 and HM2-2 ${ }^{\mathrm{T}}$ had $16 \mathrm{~S}$ rRNA gene sequences that were similar to those of $B$. catenulatum, $B$. angulatum and $B$. dentium. Levels of similarity for the partial $16 \mathrm{~S}$ rRNA gene sequence of $\mathrm{HM} 2-2^{\mathrm{T}}$ in relation to $B$. catenulatum JCM $1194^{\mathrm{T}}$, B. pseudocatenulatum JCM $1200^{\mathrm{T}}, B$. dentium ATCC $27534^{\mathrm{T}}$ and B. angulatum 


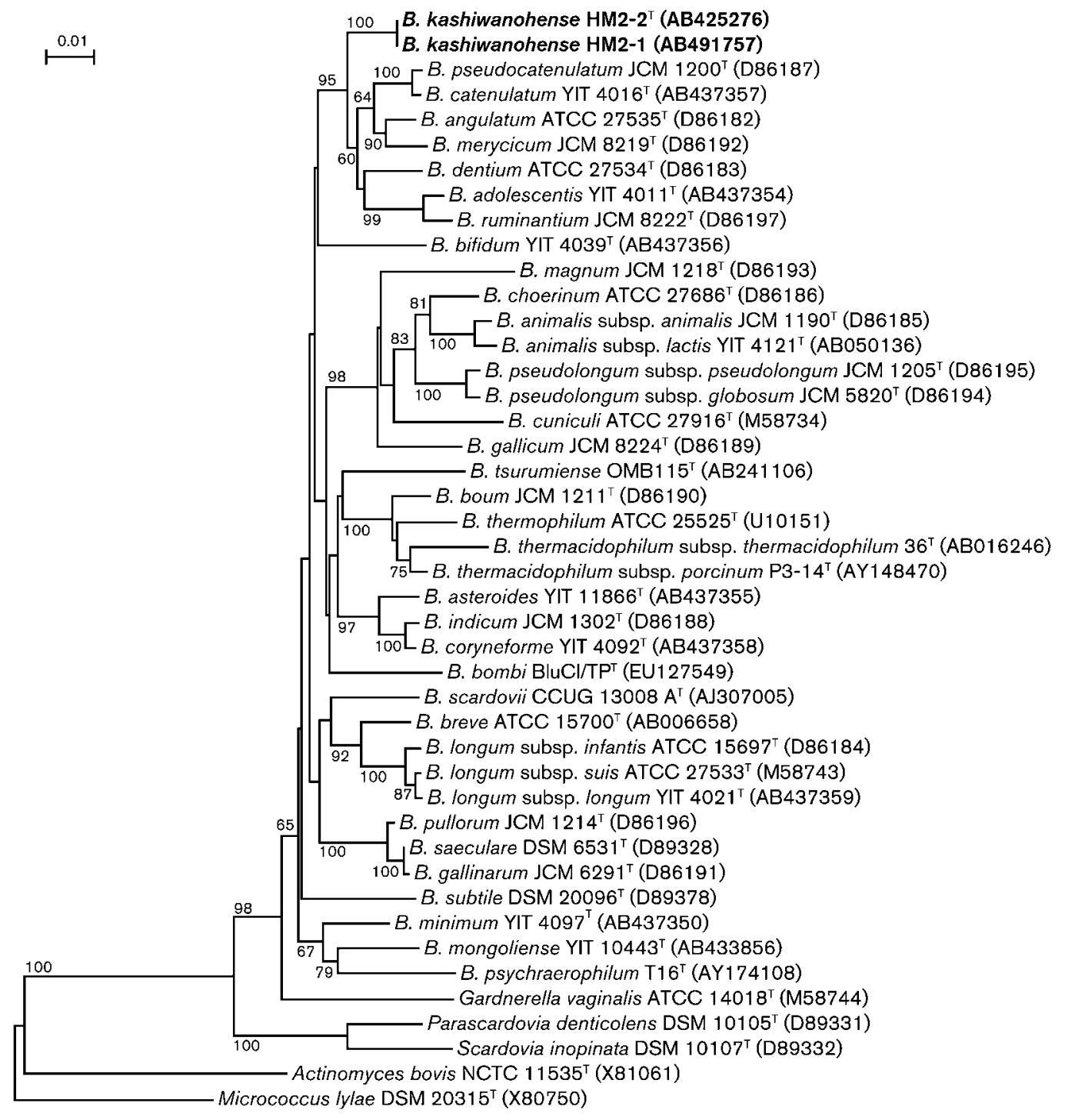

Fig. 1. Phylogenetic relationship between isolates $\mathrm{HM} 2-1$ and $\mathrm{HM} 2-2^{\top}$, species of the genus Bifidobacterium and related genera, determined by $16 \mathrm{~S}$ rRNA gene sequencing. The tree was reconstructed using the neighbour-joining method. Actinomyces bovis NCTC $11535^{\top}$ was used as an outgroup. Bootstrap percentages (based on 1000 replicates) are shown at nodes; values lower than $50 \%$ are not indicated. Accession numbers are given in parentheses. Bar, $10 \%$ difference in nucleotide sequence.

ATCC $27535^{\mathrm{T}}$ were $97.4 \%$ (1480/1520 bp), 97.2\% (1472/ $1514 \mathrm{bp}), 96.7 \%(1459 / 1509 \mathrm{bp})$ and $96.5 \%(1462 / 1515$ bp), respectively. We obtained identical tree topologies in the maximum-parsimony and maximum-likelihood analyses (Supplementary Figs S2 and S3).

Heat-shock protein ( $h s p 60$; also known as groEL, cpn60, groES or $d n a K)$ genes have also been adopted for taxonomic studies of bifidobacterial species (Jian et al., 2001; Zhu et al., 2003; Simpson et al., 2004; Delcenserie et al., 2005; Ventura et al., 2005). The partial hsp60 gene sequence of strain HM2$2^{\mathrm{T}}$ was obtained by using the conditions and primers for PCR amplification described by Jian et al. (2001) and Okamoto et al. (2008). We reconstructed a phylogenetic tree based on a total of 40 sequences of $h s p 60$ genes, including those of members of the genus Bifidobacterium and related genera (Supplementary Fig. S4). Levels of similarity for the partial $h s p 60$ gene sequence of $\mathrm{HM} 2-2^{\mathrm{T}}$ in relation to $B$. catenulatum JCM $1194^{\mathrm{T}}$, B. pseudocatenulatum JCM $1200^{\mathrm{T}}$, B. dentium ATCC $27534^{\mathrm{T}}$ and B. angulatum ATCC $27535^{\mathrm{T}}$ were $96.1 \%$ (567/590 bp), $90.8 \%$ (536/590 bp), $92.0 \%$ $(544 / 591 \mathrm{bp})$ and $89.8 \%(531 / 591 \mathrm{bp})$, respectively. The $16 \mathrm{~S}$ rRNA and $h s p 60$ gene sequences were well related and useful for determining the phylogeny of strain HM2 $-2^{\mathrm{T}}$.

Detailed characteristics of the novel isolates are provided in the species description and in Table 1, and these characteristics were compared with those of the phylogenetic relatives 
B. catenulatum JCM $1194^{\mathrm{T}}$, B. pseudocatenulatum JCM $1200^{\mathrm{T}}$, B. angulatum JCM $7096^{\mathrm{T}}$ and B. dentium JCM $1195^{\mathrm{T}}$. The isolates were able to produce $\mathrm{L}(+)$-lactic acid from $\mathrm{D}$ glucose. Anaerobic conditions were essential for the growth of strains HM2-1 and HM2-2 ${ }^{\mathrm{T}}$. These two isolates could be distinguished from $B$. pseudocatenulatum JCM $1200^{\mathrm{T}}$, B. angulatum JCM $7096^{\mathrm{T}}$ and $B$. dentium $\mathrm{JCM} 1195^{\mathrm{T}}$ by the pattern of acid production from D-mannose, cellobiose, trehalose, melezitose, dextrin, starch, inulin, D-mannitol, Dsorbitol and D-fructose. The cellular fatty acid profiles of strains HM2-1, HM2-2 ${ }^{\mathrm{T}}$ and the related genera $B$. catenulatum, B. pseudocatenulatum, B. dentium and B. angulatum are presented in Table 2 . The predominant cellular fatty acids of strains HM2-1 and HM2-2 ${ }^{\mathrm{T}}$ were $16: 0$ and $18: 1 \omega 9 c$, with proportions greater than $18 \%$ of the total.

Experimental data suggest that isolates HM2-1 and HM2$2^{\mathrm{T}}$ can be assigned to the genus Bifidobacterium on the basis of their phylogenetic position; it can be concluded that these two isolates might be considered as representing a single novel species. Thus, these two isolates represent a novel species, for which we propose the name Bifidobacterium kashiwanohense sp. nov.

\section{Description of Bifidobacterium kashiwanohense sp. nov.}

Bifidobacterium kashiwanohense (ka.shi.wa.no.hen'se. N.L. neut. adj. kashiwanohense of Kashiwanoha in Japan, which is the name of the area, University of Tokyo, where this bacterium was originally isolated).

Cells are Gram-positive, non-motile, non-spore-forming rods measuring $1.0 \times 1.3 \mu \mathrm{m}$. Colonies on $\mathrm{BL}$ agar after incubation under anaerobic conditions for 2 days at $37{ }^{\circ} \mathrm{C}$ are beige, smooth and approximately $1.0 \mathrm{~mm}$ in diameter. No growth is observed at 15 or $45{ }^{\circ} \mathrm{C}$. Produces $\mathrm{L}(+)$-lactic acid from D-glucose. Produces acid from D-xylose, D-ribose, D-mannose, cellobiose, D-sorbitol, L-arabinose, D-glucose, D-fructose, D-galactose, sucrose, maltose, lactose, melibiose, raffinose and salicin, and, to a weaker extent, from dextrin. Exhibits esterase lipase (C8), leucine arylamidase, acid phosphatase, $\alpha$-galactosidase, $\beta$-galactosidase, $\alpha$-glucosidase, $\beta$-glucosidase, and fructose-6-phosphate phosphoketolase activities. The cell wall contains glutamic acid, alanine and lysine. The DNA G + C content is $56-59 \mathrm{~mol} \%$.

The type strain is HM2-2 $2^{\mathrm{T}}\left(=\mathrm{JCM} 15439^{\mathrm{T}}=\mathrm{DSM} 21854^{\mathrm{T}}\right)$, isolated from faeces of a healthy infant (1.5 years old).

\section{Acknowledgements}

We wish to thank the Matching Fund Subsidy for financial support.

\section{References}

Biavati, B. \& Mattarelli, P. (1991). Bifidobacterium ruminantium sp. nov. and Bifidobacterium merycicum sp. nov. from the rumens of cattle. Int J Syst Bacteriol 41, 163-168.
Brenner, D. M., Moeller, M. J., Chey, W. D. \& Schoenfeld, P. S. (2009). The utility of probiotics in the treatment of irritable bowel syndrome: a systematic review. Am J Gastroenterol 104, 1033-1049, quiz 1050.

Cavalli-Sforza, L. L. \& Edwards, A. W. F. (1967). Phylogenetic analysis. Models and estimation procedures. Am J Hum Genet 19, 233-257.

Delcenserie, V., Bechoux, N., China, B., Daube, G. \& Gavini, F. (2005). A PCR method for detection of bifidobacteria in raw milk and raw milk cheese: comparison with culture-based methods. J Microbiol Methods 61, 55-67.

Ezaki, T., Hashimoto, Y. \& Yabuuchi, E. (1989). Fluorometric deoxyribonucleic acid-deoxyribonucleic acid hybridization in microdilution wells as an alternative to membrane filter hybridization in which radioisotopes are used to determine genetic relatedness among bacterial strains. Int J Syst Bacteriol 39, 224-229.

Felsenstein, J. (1985). Confidence limits on phylogenies: an approach using the bootstrap. Evolution 39, 783-791.

Fuller, R. (1991). Probiotics in human medicine. Gut 32, 439-442.

Gavini, F., Pourcher, A. M., Neut, C., Monget, D., Romond, C., Oger, C. \& Izard, D. (1991). Phenotypic differentiation of bifidobacteria of human and animal origins. Int J Syst Bacteriol 41, 548-557.

Hoyles, L., Inganäs, E., Falsen, E., Drancourt, M., Weiss, N., McCartney, A. L. \& Collins, M. D. (2002). Bifidobacterium scardovii sp. nov., from human sources. Int J Syst Evol Microbiol 52, 995-999.

Jian, W., Zhu, L. \& Dong, X. (2001). New approach to phylogenetic analysis of the genus Bifidobacterium based on partial HSP60 gene sequences. Int J Syst Evol Microbiol 51, 1633-1638.

Kluge, A. G. \& Farris, F. S. (1969). Quantitative phyletics and the evolution of anurans. Syst Zool 18, 1-32.

Komagata, K. \& Suzuki, K. (1987). Lipid and cell wall analysis in bacterial systematics. Methods Microbiol 19, 161-207.

Mikkelsen, L. L., Bendixen, C., Jakobsen, M. \& Jensen, B. B. (2003). Enumeration of bifidobacteria in gastrointestinal samples from piglets. Appl Environ Microbiol 69, 654-658.

Mitsuoka, T. (1969). [Comparative studies on lactobacilli from the faeces of man, swine and chickens]. Zentralbl Bakteriol [Orig] 210, 3251 (in German).

Okamoto, M., Benno, Y., Leung, K.-P. \& Maeda, N. (2008). Bifidobacterium tsurumiense sp. nov., from hamster dental plaque. Int J Syst Evol Microbiol 58, 144-148.

Saitou, N. \& Nei, M. (1987). The neighbor-joining method: a new method for reconstructing phylogenetic trees. Mol Biol Evol 4, 406425.

Sakata, S., Kitahara, M., Sakamoto, M., Hayashi, H., Fukuyama, M. \& Benno, Y. (2002). Unification of Bifidobacterium infantis and Bifidobacterium suis as Bifidobacterium longum. Int J Syst Evol Microbiol 52, 1945-1951.

Scardovi, V. (1986). Genus Bifidobacterium. In Bergey's Manual of Systematic Bacteriology, vol. 2, pp. 1418-1434. Edited by P. H. A. Sneath, N. S. Mair, M. E. Sharpe \& J. G. Holt. Baltimore: Williams \& Wilkins.

Scardovi, V. \& Crociani, F. (1974). Bifidobacterium catenulatum, Bifidobacterium dentium, and Bifidobacterium angulatum: three new species and their deoxyribonucleic acid homology relationships. Int $J$ Syst Bacteriol 24, 6-20.

Scardovi, V., Trovatelli, L. D., Biavati, B. \& Zani, G. (1979). Bifidobacterium cuniculi, Bifidobacterium choerinum, Bifidobacterium boum, and Bifidobacterium pseudocatenulatum: four new species and their deoxyribonucleic acid homology relationships. Int $J$ Syst Bacteriol 29, 291-311. 
Simpson, P. J., Ross, R. P., Fitzgerald, G. F. \& Stanton, C. (2004), Bifidobacterium psychraerophilum sp. nov. and Aeriscardovia aeriphila gen. nov., sp. nov., isolated from a porcine caecum. Int J Syst Evol Microbiol 54, 401-406.

Tan, Y., Wu, M., Liu, H., Dong, X., Guo, Z., Song, Z., Li, Y., Cui, Y., Song, Y. \& other authors (2010). Cellular fatty acids as chemical markers for differentiation of Yersinia pestis and Yersinia pseudotuberculosis. Lett Appl Microbiol 50, 104-111.

Thompson, J. D., Higgins, D. G. \& Gibson, T. J. (1994). ClusTAL W: improving the sensitivity of progressive multiple sequence alignment through sequence weighting, position-specific gap penalties and weight matrix choice. Nucleic Acids Res 22, 4673-4680.

Ventura, M., Zink, R., Fitzgerald, G. F. \& van Sinderen, D. (2005). Gene structure and transcriptional organization of the dnaK operon of Bifidobacterium breve UCC 2003 and application of the operon in bifidobacterial tracing. Appl Environ Microbiol 71, 487-500.

Ventura, M., O'Flaherty, S., Claesson, M. J., Turroni, F., Klaenhammer, T. R., van Sinderen, D. \& O'Toole, P. W. (2009).
Genome-scale analyses of health-promoting bacteria: probiogenomics. Nat Rev Microbiol 7, 61-71.

Wayne, L. G., Brenner, D. J., Colwell, R. R., Grimont, P. A. D., Kandler, O., Krichevsky, M. I., Moore, L. H., Moore, W. E. C., Murray, R. G. E. \& other authors (1987). International Committee on Systematic Bacteriology. Report of the ad hoc committee on reconciliation of approaches to bacterial systematics. Int J Syst Bacteriol 37, 463-464.

Weisburg, W. G., Barns, S. M., Pelletier, D. A. \& Lane, D. J. (1991). $16 \mathrm{~S}$ ribosomal DNA amplification for phylogenetic study. J Bacteriol 173, 697-703.

Whorwell, P. J., Altringer, L., Morel, J., Bond, Y., Charbonneau, D., O'Mahony, L., Kiely, B., Shanahan, F. \& Quigley, E. M. (2006). Efficacy of an encapsulated probiotic Bifidobacterium infantis 35624 in women with irritable bowel syndrome. Am J Gastroenterol 101, 1581-1590.

Zhu, L., Li, W. \& Dong, X. (2003). Species identification of genus Bifidobacterium based on partial HSP60 gene sequences and proposal of Bifidobacterium thermacidophilum subsp. porcinum subsp. nov. Int J Syst Evol Microbiol 53, 1619-1623. 